\title{
METHODICAL EXPERIENCE OF CONSTRUCTING THE SYSTEM OF CONTINUOUS DEVELOPMENT OF HIGHER EDUCATIONAL INSTITUTIONS STUDENTS
}

\author{
Anton Khodunov ${ }^{1}$, Anton Akopyan ${ }^{2}$, Anna Vorotyntseva ${ }^{3}$, Lyudmila Komyshova ${ }^{4}$ \\ ${ }^{1}$ Vice-rector for educational work, Voronezh State Technical University, 20 years of October Street, \\ 84, Voronezh, Russia, E-mail: CmiVGASU@mail.ru \\ ${ }^{2}$ Acting Dean of the Faculty of Culture and Education, Voronezh State Technical University, 20 \\ years of October Street, 84, Voronezh, Russia, E-mail: akop_antoxa@mail.ru \\ ${ }^{3}$ Candidate of Economics Sciences, Associate Professor, Voronezh State Technical University, \\ 20 years of October Street, 84, Voronezh, Russia, E-mail: allslavin@mail.ru \\ ${ }^{4}$ Senior teacher, Voronezh State Technical University, \\ 20 years of October Street, 84, Voronezh, Russia, E-mail: mila_kom@mail.ru
}

\begin{abstract}
The article discusses the experience of the methodological experience of building a system of continuous development of students on the basis of higher educational institutions.

The relevance of the study of building a system of continuous development of students on the basis of higher education institutions is due to a significant change in the needs of society. The formation of the system of lifelong education currently necessary for society, aimed at developing human potential, ensuring the current and future needs of the country's socio-economic development, will help to increase public satisfaction with the existing quality of educational services provided.

The need is identified for providing highly qualified personnel in the priority areas of modernization and technological development, as well as creating conditions for general and professional education, advanced training and retraining of personnel throughout life. The methodological experience provides for a number of educational measures for the development of students, which meets one of the main tasks facing the state, which is to ensure high quality continuing education in accordance with the changing demands of the population and the promising tasks of the development of Russian society and the economy.
\end{abstract}

Keywords: continuing education, continuous development, supra-professional competencies, talented youth, educational events

\section{INTRODUCTION}

The question of career guidance (also in scholarship period) of future employees of different spheres of national and world economy is still actual in modern world of changing trends. Those future employees are students of high school, secondary vocational education student and schoolars. This is not only and sometimes not so much important, because you can change your profession at any time, this is allowed by modern continuous, starting from school, education ("A ticket to the future", NTI circles) due to the progress of science and technology and the widespread use of innovative technologies. 
No less, and perhaps more relevant, is the system of comprehensive development of the future employee, pumping of his "hard" (professional) and "flexible" (supraprofessional, interprofessional) competencies and skills. Modern universities, which strive to move in the stream of new trends, should direct their gaze on the development of this field of activity, they should promptly respond to the growing demands of technology, economics and humanitarian areas, and build on their basis a system of continuous development of students.

\section{METHODOLOGY}

In their activities in the field of building the above described system, educational organizations should rely on the following basic documents:

- Decree of the President of the Russian Federation "On National Goals and Strategic Tasks of the Development of the Russian Federation for the Period until 2024"

- National project "Education",

- National program "Digital Economy of the Russian Federation"

Actions under the Decree of the President of the Russian Federation "On National Goals and Strategic Tasks of the Development of the Russian Federation for the Period until 2024" (May 20, 2018 No. 204) are aimed at ensuring the accelerated implementation of digital technologies in the economy and social sphere and include:

- Acceleration of technological development of the Russian Federation,

- Increase in the number of organizations implementing technological innovations, up to 50 percent of their total number;

- Ensuring the accelerated implementation of digital technologies in the economy and social sphere.

This ensures the necessity to stimulate the system of continuous development within the framework of the modern education system.

It is not a secret that digital technologies are the most actively developing in modern world. Forming LCDS should take this fact into account, as well as those key aims, that are included in national program "Digital Economy of the Russian Federation", federal project "Personnel for the digital economy" more precisely:

- Creating a system of motivation for citizens to master the competencies of the digital economy,

- Transformation of the labor market in accordance with the requirements of the digital economy.

- Improving the education and training system for the digital economy of the Russian Federation,

Taking into account all the transformations of the modern world, a national program "Education" was developed. The key objectives of this national project are:

- Ensuring the global competitiveness of Russian education,

- The entry of the Russian Federation among the 10 leading countries of the world in the quality of general education,

- Education of a harmoniously developed and socially responsible person on the basis of spiritual and moral values of the peoples of the Russian Federation, historical and national-cultural traditions.

The national Education program includes 10 federal projects:

- Federal project "Modern School",

- Federal project "Success of every child",

- Federal project "Support for families with children",

- Federal project "Digital educational environment",

- Federal project "Teacher of the future",

- Federal project "New opportunities for everyone"

- Federal project "Social activity",

- Federal project "Young Professionals", 
- Federal project "Social upward mobility for everyone",

- Federal project "Export of education".

\section{DISCUSSION}

As can be seen from all of the above, centers of continuous additional education should be created on the basis of universities. The organizational structure of such system may have the form shown in Figure 1. This organizational structure is being implemented at the Voronezh State Technical University (Voronezh Basic University), so the figure will contain links to the structural units of this institution. Further, the article will describe the experience of building a system of continuous development on the basis of VSTU.VSTU developments can be used as an algorithm or a scheme in the formation of similar systems in other both domestic and foreign universities.

As we see from the figure, the structure of the LCDS is quite extensive and includes all stages of the socalled continuing education (development): school-university-postgraduate education.

It is worth noting that, within the framework of the presented scheme, it was not possible to reflect the relationship with other structural units of the university in question: faculties and departments, including basic ones, departments, centers and laboratories, although the LCDS are closely related to them, and they are part of the resource ecosystems of LCDS.

It is worth paying special attention to the fact that the collective work space "Boiling point of VSTU", which is part of the All-Russian network of "Boiling Points", began its work on the basis of VSTU in October 2019. The curator of the Collective Space "VGTU Boiling Point" is Vice-Rector for Digitalization and Innovation Activities Sklyarov K.A., who, due to his professional activities and interest, provides comprehensive support to the LCDS.

The boiling point of VSTU is a space on the basis of which representatives of the field of education, science and business, scientists and businessmen, technological entrepreneurs, civil servants and members of public organizations, students, theorists and practitioners can share their experiences, talk about the results of their activities, work out new models the development of the region both individually (in its own areas) and in interaction with each other. A collective work space in which each person or team is involved in the implementation of the Strategic Initiatives Agency (SIA) agenda gets free access to knowledge, authoritative experts, new ideas and technologies, therefore, this space is one of the ways to efficiently provide resources for the LCDS, which is confirmed the goals and objectives of its creation and functioning (Figure 2).

In figure 1, some of its components are clearly highlighted and this was not done by chance. These are the points of the scheme that we will consider in more detail.

In the fall of 2017, the Development of Talented Youth Center was established as part of the teaching and educational faculty, which proved its effectiveness and the need for this. The given moment is in the subordination of the faculty and the management of educational work.

The Development of Talented Youth Center (DTYC) is a voluntary association of teachers and students created to improve the quality of their training, identify gifted youth, create a creative approach to a future profession, develop professional competencies on the basis of project activities using the educational and scientific potential of the relevant departments and faculties and scientific divisions of VSTU.

First of all, the creation of DTYC was dictated by the need to develop a mentoring system at the university. It was on the development of the mentoring system that Putin V. emphasized in his message to the Federal Assembly of March 1, 2018. "I consider the development of the mentoring movement a significant task. Only in this way, combining advanced knowledge and moral foundations, ensuring genuine partnership and mutual understanding of generations, we can be strong ... Today, the most important competitive advantage is knowledge, technology, and competencies. This is the key to a real breakthrough, to improving the quality of life."

Mentoring - activity in the field of individualization of education, including:

- Clarification of educational motives, professional interests and competencies of the student;

- The choice of educational resources to create an individual educational path;

- Work on vocational guidance;

- The formation of educational and professional reflection of the student.

The goals and objectives of the DTYC are presented in Figure 3. 


\section{Higher educational institution (VSTU)}

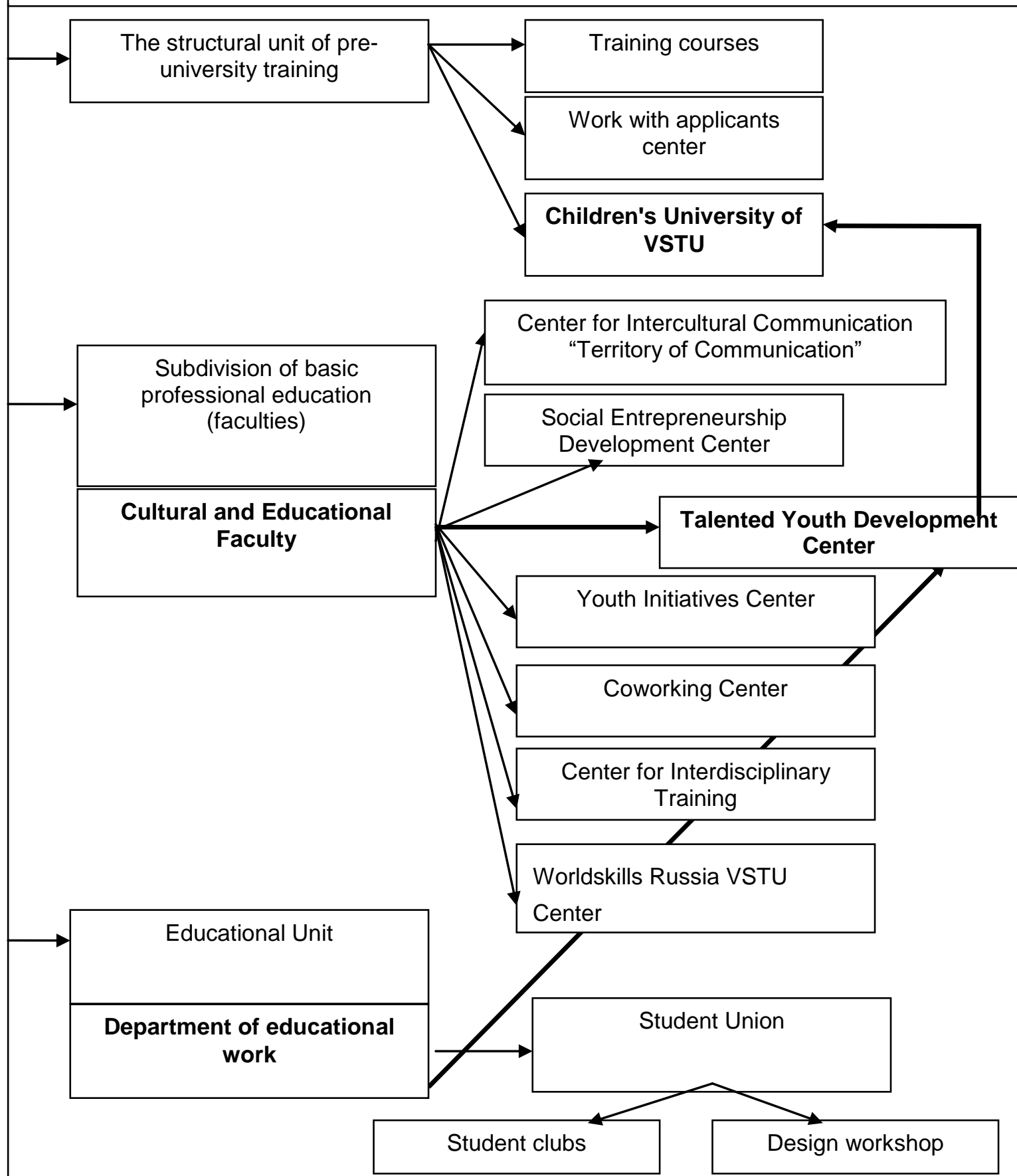

Subdivision of vocational training and retraining

Faculty of Continuing Professional Education

Figure 1 - Learning Continuous Development System (LCDS) 


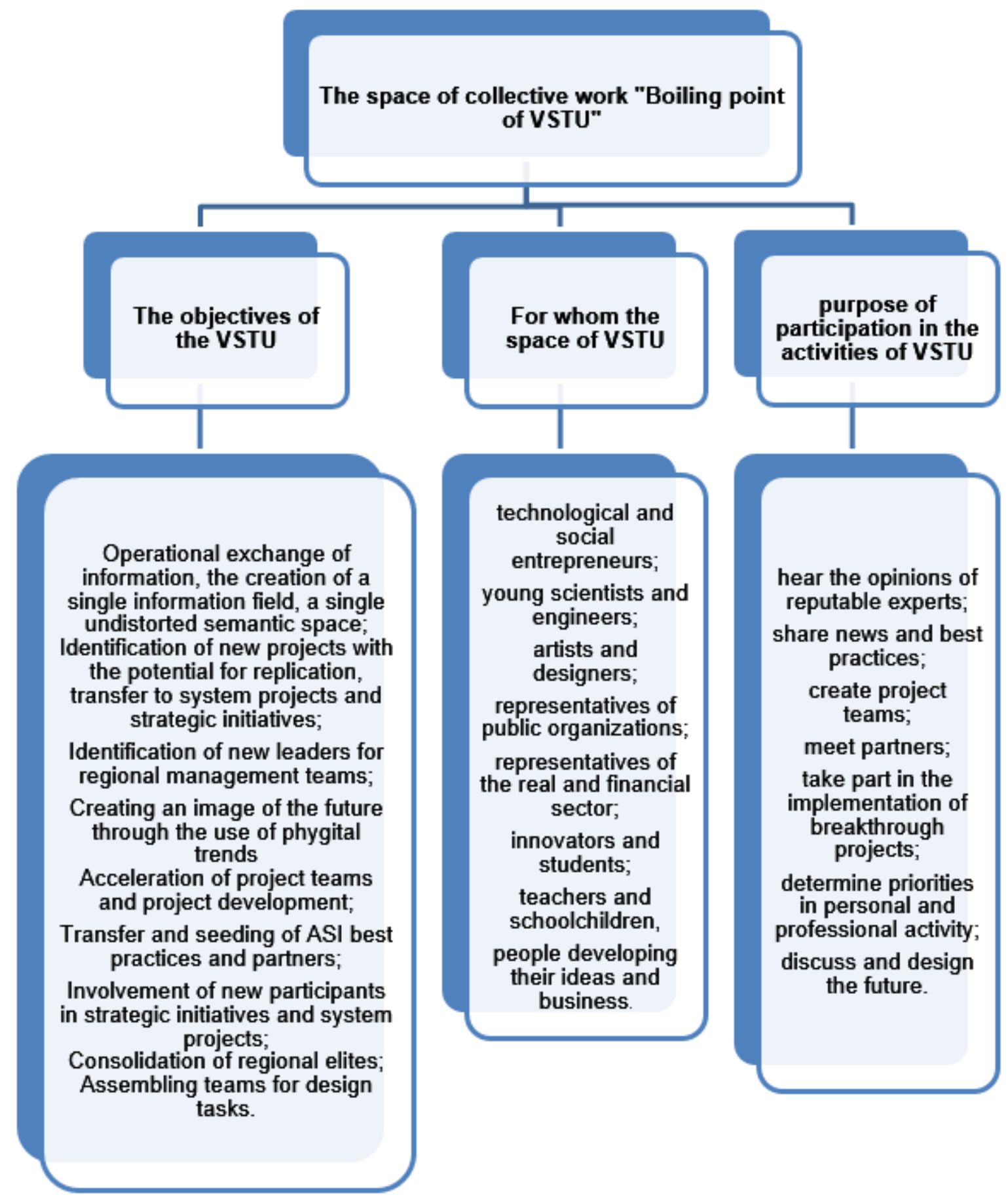

Figure 2 - Goals and objectives of the functioning of the Space of collective work "Boiling point of VSTU" 


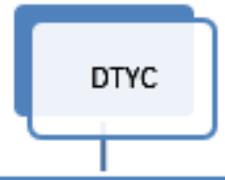

Aims of DTYC:

the formation of an effective system for the development of talented youth through the modernization of the educational process at VSTU on the basis of the mechanism of mentoring and development of project activities to preserve and increase the human capital of the region and the development of entrepreneurship;

creation and development of favorable conditions for the intensification of project activities of students;

providing an opportunity for each resident of the MDTC to exercise their right to the creative development of the individual in accordance with his abilities and needs.

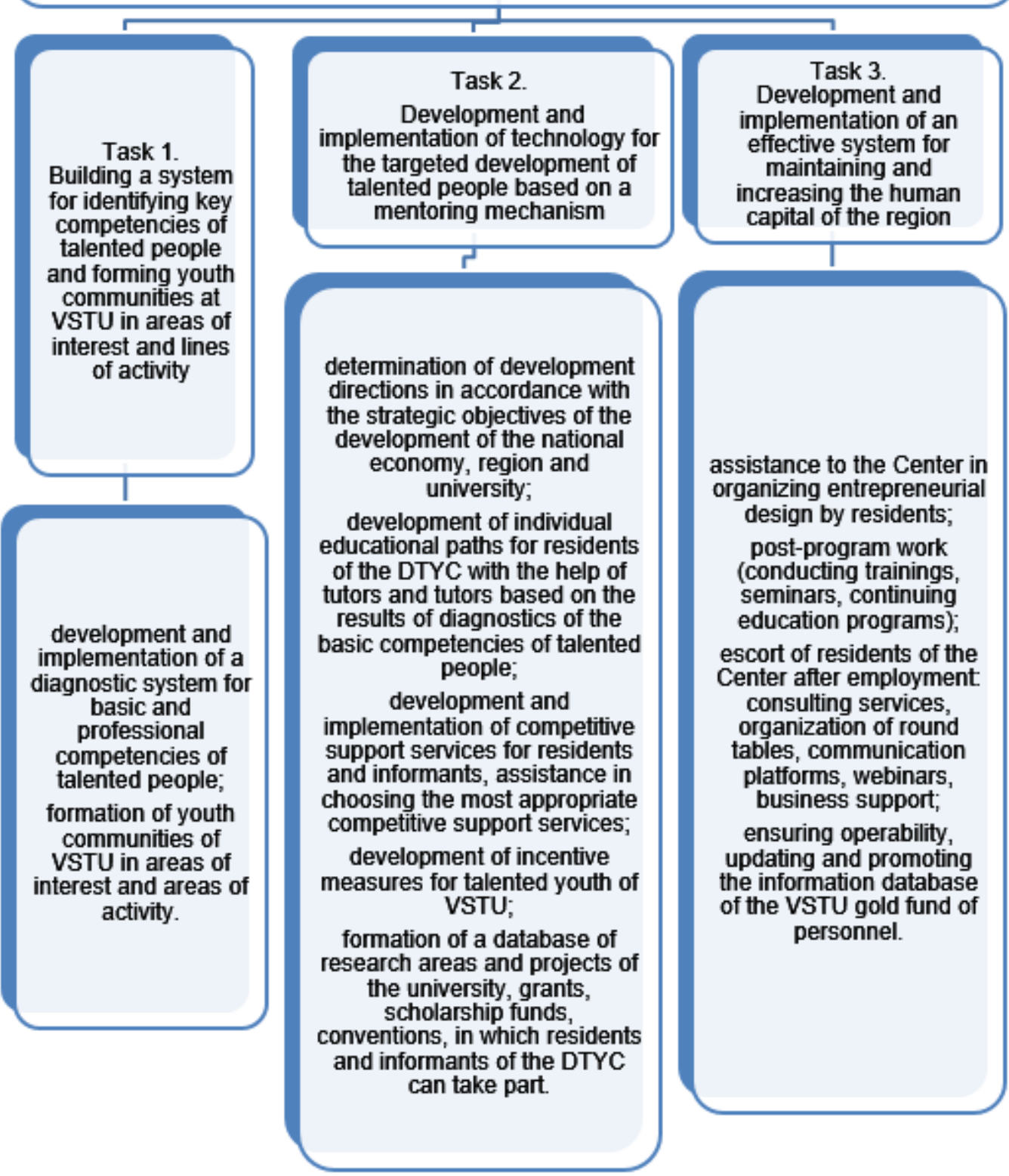

Figure 3 - Goals and objectives of the DTYC 
DTYC (as can be seen from Figure 1) is closely interconnected with other centers and structural divisions of VSTU, which are part of the Cultural and Educational Faculty and the Department of Educational Work, in particular with the Center for Interdisciplinary Education, as their joint activities are aimed at comprehensive development future employee, pumping his "hard" (professional) and "flexible" (supraprofessional, interprofessional) competencies and skills.

The activity of the DTYC is focused on 3 main age categories:

- Juniors Grades 5-8,

- Teenagers Grades 9-11 + STR

- Young HPE + graduate

As part of the work in the Juniors age category, the 5-8th grade on the basis of the TsRTM in 2020 began working in a test mode Children's University of VSTU (CU VSTU). The creation of this educational center is based on the fulfillment of targets set by the federal project "Success of every child", which is being implemented within the framework of the national program "Education", which was mentioned above.

According to the federal project "Every Child's Success", the number of school-age children employed in continuing education should increase from 71 to $80 \%$ by the end of 2024 . In the framework of university activities, centers should be created that implement additional general educational programs at universities. the number of these centers should be increased from 15 to 100, and the number of children involved from 6,000 to 40,000 .

The goal of the creation of the CU VSTU is to conduct educational and enlightenment activities among schoolchildren, to generate interest in science and creativity, the social and cultural spheres of life from a very early age, and to conduct early career guidance work. The target audience of the CU VSTU is shown in Figure 4, and the main activities are presented in Figure 5. Table 1 shows planned educational activities, which are suggested to hold on every of thematic areas. It is planned that classes for the preschool category can be held throughout the day, for students in the afternoon and in the evening. It is supposed to create a system of the so-called extended-day group and to organize group and individual classes in general subjects within the framework of cooperation in the preparatory courses of VSTU in the scientific and technical thematic direction.

It should be noted that students of VSTU take an active part in organizing the activities of the CU VSTU, they are leaders of thematic circles, some of which were created precisely on their initiative. We can say that the students 'activities within the framework of the CU VSTU are also part of the student's continuous development system, as well as their acquisition of new professional skills.

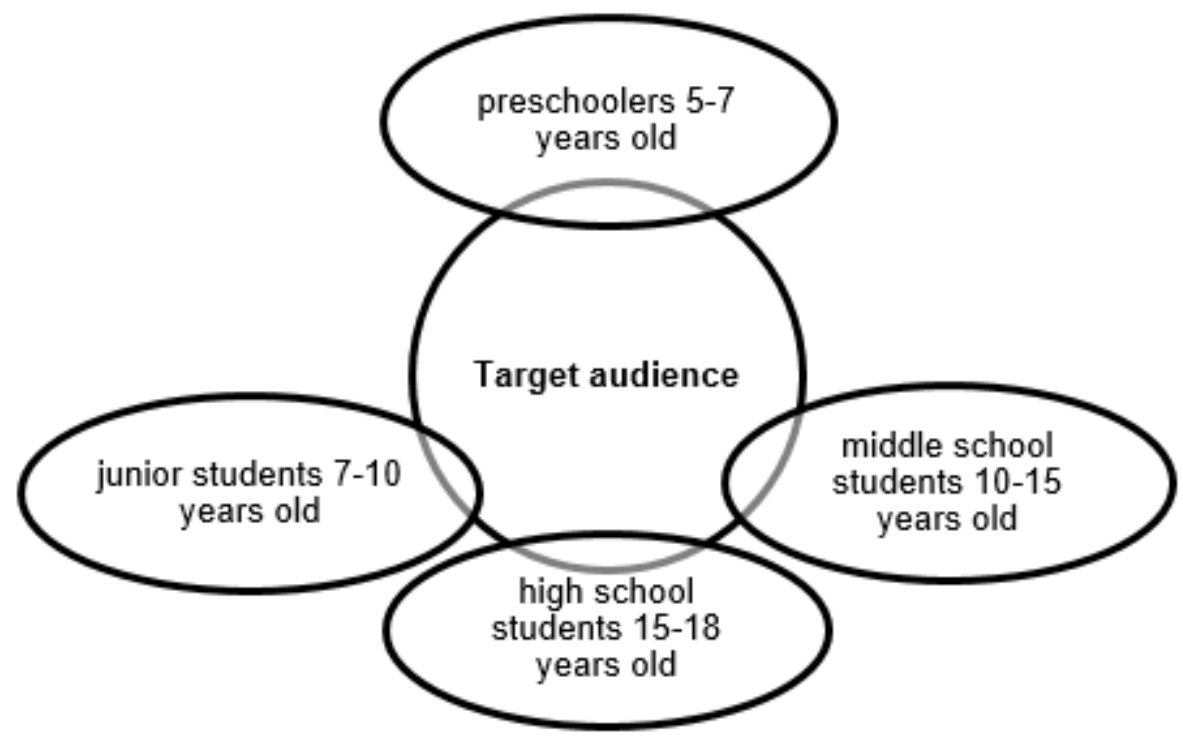

Figure 4 - Target audience of the VSTU 


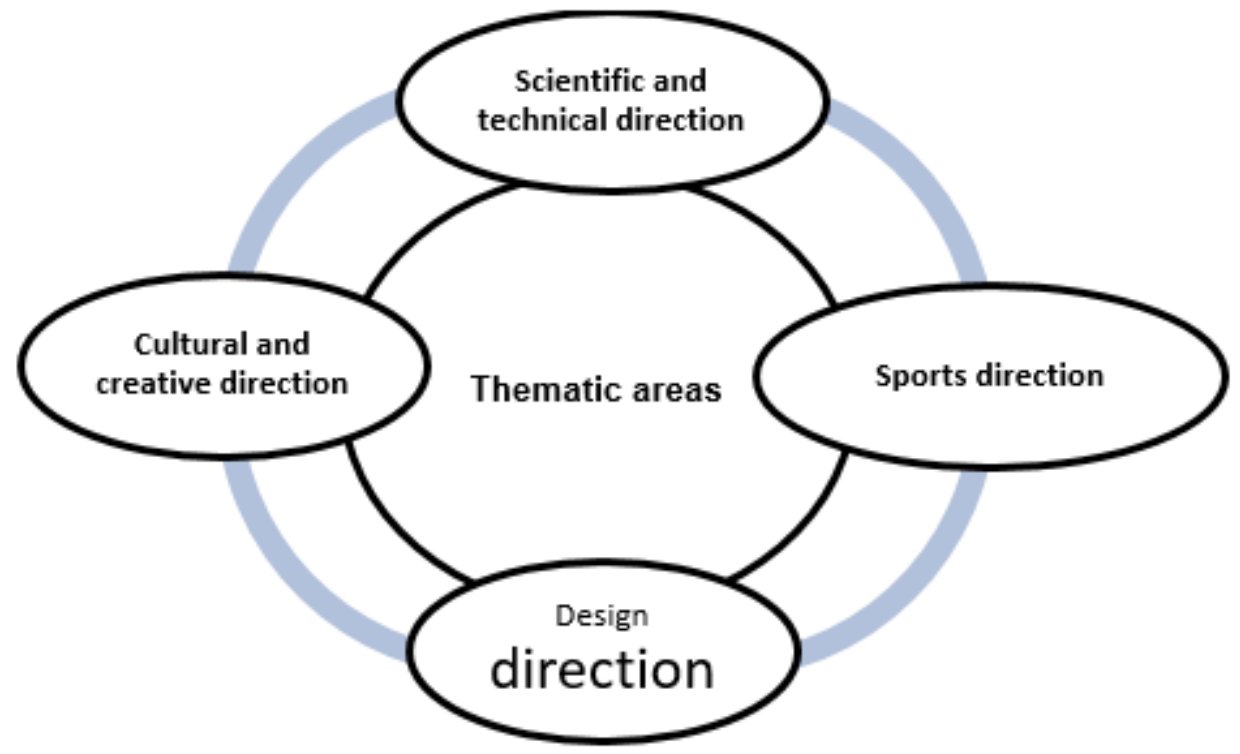

Figure 5 - Thematic areas of activity of the VSTU

Table 1 Educational activities carried out within the framework of thematic areas.

\begin{tabular}{|c|c|c|c|}
\hline $\begin{array}{c}\text { Scientific and } \\
\text { technical direction }\end{array}$ & $\begin{array}{l}\text { Cultural and creative } \\
\text { direction }\end{array}$ & Sports direction & $\begin{array}{l}\text { Design } \\
\text { direction }\end{array}$ \\
\hline $\begin{array}{l}\text { The basis of } \\
\text { prototyping (making } \\
\text { models of houses, } \\
\text { ships, etc.); } \\
\text { Robotics; } \\
\text { Robotics using } \\
\text { LEGO; } \\
\text { Mental arithmetic; } \\
\text { The world around } \\
\text { us - chemistry, } \\
\text { biology, physics, etc } \\
\text {;; } \\
\text { Computer graphics, } \\
\text { 3D modeling; } \\
\text { VR lab; } \\
\text { Classes in general } \\
\text { subjects (group and } \\
\text { individual). }\end{array}$ & $\begin{array}{c}\text { Creative workshops in the } \\
\text { areas of: } \\
\text { Vocal, } \\
\text { Dance, } \\
\text { Acting, } \\
\text { Theatre studio, } \\
\text { Oratory, } \\
\text { Design Studio "Steps", } \\
\text { Pottery, } \\
\text { Sand animation, } \\
\text { Learning foreign } \\
\text { languages,uncluding. vocal } \\
\text { and theatrical direction; } \\
\text { KVN Junior League } \\
\text { Developing activities for } \\
\text { the little ones. } \\
\text { Historical direction: } \\
\text { Museum work; } \\
\text { Archeology; } \\
\text { Organization and conduct of } \\
\text { outdoor excursion events in } \\
\text { the university and the city. }\end{array}$ & $\begin{array}{l}\text { Chess Club } \\
\text { ESports Club }\end{array}$ & $\begin{array}{l}\text { Project Ideas Workshop } \\
\text { Children's Economic } \\
\text { University VSTU } \\
\text { Board Game Club } \\
\text { "Monopoly" } \\
\text { Media Direction: } \\
\text { The work of student } \\
\text { television - the study of } \\
\text { editing and shooting; } \\
\text { The work of a photo studio - } \\
\text { a darkroom and digital } \\
\text { image processing; } \\
\text { Game design; } \\
\text { Blogging and Youtube } \\
\text { Channels } \\
\text { Leadership: } \\
\text { The program "I am the } \\
\text { leader." 21st Century Skills. } \\
\text { The program "Through } \\
\text { labor to success" - the } \\
\text { activities of student groups, } \\
\text { work "hands". }\end{array}$ \\
\hline
\end{tabular}




\section{RESULTS}

Today, all developed countries of the world are implementing programs aimed at the formation and sustainable development of a lifelong education system - life-long learning, in which the share of the economically active population of the country can reach $60-70 \%$. Particularly significant characteristics of educational trends, as the only potential for the development of human capital, are the ability and ability of a person to learn throughout his life. At the same time, the development of abilities and the provision of various opportunities for obtaining the necessary knowledge become strategic priorities that help form the foundations of the future.

\section{CONCLUSION}

Higher educational organizations create conditions that ensure the use of new teaching technologies in a modern transparent information environment. Currently, there is a large-scale implementation and use of approved educational models and programs in the priority areas of modernization of education, a qualitatively new level of individualization of education is being provided, which allows educational paths to be realized in organizations of all forms of ownership and their networks, in the forms of distance education, self-education, to ensure continuous development students.

\section{REFERENCE LIST}

Vorotyntseva A., Belousov V, Komyshova L., Andrunina Ya. (2019). Introduction of the VSTU interdisciplinary education system // Economics of investment and construction complex and housing and communal services. № 2 (17) P. 89-95. (in Russian).

Komyshova L. (2013). The development of a methodological system of advanced professional retraining of managers and specialists of organizations // Finance. Economy. № 3. P.48 (in Russian).

Petrenko V. R., Korshunova S. A., Maslikhova L. I., (2019) Achievements of technical education of the Voronezh region as a guarantee of successful development of the country and the region (rev. On the book: 110 years of technical education of the voronezh region : anniversary edition. Voronezh : VSTU publishing house, 2018. 240 p). Bulletin of the Voronezh state University. Series: Problems of higher education № 4. Pp. 114-117. (in Russian).

Ordinance No. 22 of March 1, 2019 "On the approval of guidelines for the establishment and operation of centers implementing additional general education programs in organizations engaged in educational activities in higher education educational programs, including those involved in the creation of world scientific and research centers level or supporting centers of competence of the National Technology Initiative "

Passport of the national program "Digital Economy of the Russian Federation", approved at the meeting of the Presidium of the Presidential Council for Strategic Development and National Projects on December 24, 2018 (the Ministry of Communications of the Russian Federation pursuant to Decree of the President of the Russian Federation of May 7, 2018 No. 204 "On National Goals and strategic objectives of the development of the Russian Federation for the period until 2024 " (in Russian).

Passport of the federal project "Personnel for the Digital Economy", approved by the Presidium of the Government Commission on Digital Development, the use of information technology to improve the quality of life and the conditions for doing business (protocol of May 28, $2019 \mathrm{~N} \mathrm{9)/(in} \mathrm{Russian).}$

Passport of the national project "Education", approved at the end of the meeting of the Presidium of the Presidential Council for Strategic Development and National Projects on December 24, 2018 (the Ministry of Education of Russia pursuant to Decree of the President of the Russian Federation of May 7, 2018 No. 204 "On National Goals and Strategic Tasks development of the Russian Federation for the period until 2024 "). (in Russian).

The Decree of the President of the Russian Federation "On National Goals and Strategic Tasks of the Development of the Russian Federation for the Period until 2024" (May 20, 2018 No. 204)/ (in Russian).

Uvarova S., Vorotyntseva A, Belyaeva S., Rogacheva Ya. (2018). The development of the mentoring mechanism at the university in terms of the project approach A. // Finance. Economy. T. 15, №.5 P. 
Proceedings of SOCIOINT 2020- 7th International Conference on Education and Education of Social Sciences, 15-17 June 2020

24-29. (in Russian).

Uvarova S. Belyaeva S, Myshovskaya L., Belyantseva O. (2018) Mentoring as a tool to improve the training of highly qualified specialists in construction // Economics and Entrepreneurship.№ 1 (90) .P. 672677. (in Russian). 